Original Article

\title{
Reproductive diseases in captive Agoutis (Dasyprocta leporina)
}

\author{
Doenças reprodutivas em cutias em cativeiro (Dasyprocta leporina)
}

\author{
K. R. Jones ${ }^{\mathrm{a}, \mathrm{b} *}$ (D), K. R. Lall ${ }^{\mathrm{b}}$ (D) and G. W. Garcia ${ }^{\mathrm{b}}$ (D) \\ ${ }^{a}$ The University of the West Indies - UWI, Faculty of Medical Sciences - FMS, School of Veterinary Medicine - SVM, Department of Basic Veterinary \\ Sciences - DBVS, Mt. Hope, Trinidad and Tobago. \\ ${ }^{\mathrm{b}}$ The University of the West Indies - UWI, Faculty of Food and Agriculture - FFA, Department of Food Production - DFP, The Open Tropical Forage- \\ Animal Production Laboratory - OTF-APL, St. Augustine, Trinidad and Tobago.
}

\begin{abstract}
Reproductive diseases have been well documented in domestic livestock such as sheep, goat, cattle and pigs. However, there is very little information on these diseases in the agouti (Dasyprocta leporina). The agouti is used for its meat in South America and the Caribbean. More recently, intensive farming of this animal is being practiced in the Neotropics. There is dearth of information on dystocia and vaginal prolapses in the agouti. This document reports on three cases of reproductive diseases in captive reared agoutis in Trinidad and Tobago. The first case was a female agouti weighing approximately $3 \mathrm{~kg}$ that was in the last stage of pregnancy, which was found dead in its cage. The vulva of the mother had the protruding hind-limbs of the fetus. Necroscopic evaluation of carcass revealed little fat tissue and the mother had two fetuses in the right horn of the uterus. Each fetus weighed approximately $200 \mathrm{~g}$. The fetuses were well formed with fur, teeth and eyes. The placenta was attached to each fetus. The pathological findings suggested that dystocia resulted from secondary uterine inertia which was the cause of death of the adult female agouti. The second case was that of an adult female agouti weighing $2.5 \mathrm{~kg}$. This female had given birth to an offspring three weeks prior and was observed to have had a vaginal prolapse. Surgery was performed and the prolapsed vagina was placed back into the pelvic cavity. Further to this intervention, the vagina prolapsed twice. Subsequent to the re-insertion of the vaginal tissue the agouti was euthanized. The third case was also that of a dystocia. However, the fetuses weighed $235 \mathrm{~g}$ and $165 \mathrm{~g}$ respectively and were in normal presentation, posture and positioning. The fetus however was unable to pass via the vagina and was trapped in the pelvic cavity. This caused secondary uterine inertia which was the cause of death. The causes of reproductive diseases in these cases are unknown but the feeding management and space allowance given to the agouti in late gestation may be contributing factors.
\end{abstract}

Keywords: neotropics, uterine inertia, dystocia, vaginal prolapse, reproductive diseases.

\begin{abstract}
Resumo
As doenças reprodutivas têm sido bem documentadas em rebanhos domésticos, como ovinos, caprinos, bovinos e suínos. Porém, há muito pouca informação sobre essas doenças na cutia (Dasyprocta leporina). A cutia é usada como carne na América do Sul e no Caribe. Mais recentemente, a criação intensiva desse animal está sendo praticada na região neotropical., Há escassez de informações sobre distocia e prolapsos vaginais na cutia. Este documento relata três casos de doenças reprodutivas em cutias criadas em cativeiro em Trinidad e Tobago. $O$ primeiro caso foi de uma cutia de aproximadamente $3 \mathrm{~kg}$ que estava na última fase de gestação, encontrada morta em sua gaiola. A vulva da mãe tinha as patas traseiras salientes do feto. A avaliação necroscópica da carcaça revelou pouco tecido adiposo e a mãe tinha dois fetos no corno direito do útero. Cada feto pesava aproximadamente $200 \mathrm{~g}$. Os fetos eram bem formados com pelos, dentes e olhos. A placenta foi presa a cada feto. Os achados patológicos sugeriram que a distocia resultou de inércia uterina secundária, que foi a causa da morte da cutia adulta. O segundo caso foi o de uma cutia adulta pesando $2,5 \mathrm{~kg}$. Essa fêmea deu à luz uma cria três semanas antes e foi observado que tinha prolapso vaginal., A cirurgia foi realizada e a vagina prolapsada foi colocada de volta na cavidade pélvica. Após essa intervenção, a vagina prolapsou duas vezes. Após a reinserção do tecido vaginal, a cutia foi eutanasiada. $O$ terceiro caso também foi de distocia. No entanto, os fetos pesavam $235 \mathrm{~g}$ e $165 \mathrm{~g}$ e estavam em apresentação, postura e posicionamento normais. $\mathrm{O}$ feto, entretanto, não conseguiu passar pela vagina e ficou preso na cavidade pélvica. Isso causou inércia uterina secundária, que foi a causa da morte. As causas das doenças reprodutivas nesses casos são desconhecidas, mas o manejo da alimentação e o espaço concedido à cutia no final da gestação podem ser fatores contribuintes.
\end{abstract}

Palavras-chave: Neotropics, inércia uterina, distocia, prolapso vaginal, doenças reprodutivas.

*e-mail: keganjones11@gmail.com

Received: May 11, 2020 - Accepted: August 10, 2020

This is an Open Access article distributed under the terms of the Creative Commons Attribution License, which permits unrestricted use, distribution, and reproduction in any medium, provided the original work is properly cited. 


\section{Introduction}

The agouti (Dasyprocta leporina) is a rodent that belongs to the hystricomorphic group of rodents. It is one of the most hunted species in the Caribbean and South America (Brown-Uddenberg et al., 2004). However, the exploitation of these animals in the wild can lead to decreasing numbers in wild populations. This rodent lives in social groups in its natural habitat (Lall et al., 2020). Alternatively, the use of mini-livestock has the potential to become meat protein for rural communities in the Neotropics (Hardouin et al., 2003). Health and diseases in this Neotropical rodent has been less frequently reported than other species. The majority of diseases highlighted have been related to some infectious agent. Lall et al., (2018) reviewed infectious diseases present in the agouti and found that few animals showed clinical signs of diseases. This made the agouti a major reservoir of infectious pathogens for domestic animals. However, little reports existed on non-infectious diseases of the agouti. Imbalances in vitamin D have been highlighted (Kenny et al., 1993; Anderson et al., 2018) but there is a dearth of information on non-infectious reproductive diseases. Dystocia has been reported in other domesticated rodents such as the guinea pig (Cavia porcellus) (Minarikova et al., 2015), and chinchilla (Chinchilla lanigera) (Saunders, 2009). However, it is usually associated with an oversized foetus or malposition (Saunders, 2009). Intrauterine asphyxia has been diagnosed in wild cavies (C. porcellus), viscachas (Lagostomus maximus) and capybaras (Hydrochoerus hydrochaeris) (Rubel, 1999). Dystocia has also been recorded in captive reared viscacha (L. maximus) (Rubel, 1999).

Some authors have observed perinatal mortality in captive reared agoutis in Trinidad. There was one reported case in Trinidad in which an agouti died from secondary uterine inertia due to dystocia. In that case the adult female was reported to have had six offspring. Three were delivered via the vagina but the remaining offspring were removed via caesarean section (Singh and Garcia 2015). In Brazil, pathological changes of the reproductive system of captive reared breeding females were investigated. Dystocia was reported in $7.7 \%$ of breeding females. In that case of dystocia there was one large fetus present in a uterine horn (Batista et al., 2016). Batista et al. (2010) also reported a prevalence of $6.24 \%$ for dystocia in captive reared agoutis. To the authors' knowledge a case of vaginal prolapse in the agouti has never been reported in the literature. Thus, the objective of this report was to highlight findings of two dystocia cases and a vaginal prolapse in two agoutis reared intensively in Trinidad and Tobago.

There have been few reports on diseases affecting the agouti in captivity at the UFS. Some of these diseases have been listed in Table 1 . However, these animals can harbor micro-organisms that can be zoonotic or decrease the productivity of its host. Investigations have been undertaken on the gastrointestinal parasites common to the agouti reared in captivity and in the wild (Suepaul et al., 2016; Jones and Garcia, 2017; Jones and Garcia, 2018; Griffiths, 1940; Cameron and Reesal, 1951; Lainson et al., 2007). Blood parasites such as Babesia, Leishmania and Trypanosoma cruzi (Ayala et al., 1973;
Table 1. Information on Reproductive parameters and diseases recorded in the Breeding colony at the University Field Station (UFS).

\begin{tabular}{cc}
\hline Parameters & Values \\
\hline $\begin{array}{c}\text { Adult body weight (Male } \\
\text { and Female) }(\mathrm{kg}) \\
\text { Gestation Period (days) } \\
\text { Litter Size (no. of offspring } \\
\text { per litter) }\end{array}$ & $2-3.5$ \\
Birth Weight (g) & $103-110$ \\
& $140-330(210 \pm 35)$ \\
$\begin{array}{c}\text { Diseases identified at the } \\
\text { breeding colony }\end{array}$ & $\begin{array}{c}\text { Salmonellosis, Colibacillosis, } \\
\text { Mammary hyperplasia, } \\
\text { Vaginal prolapse, Dystocia, } \\
\text { Scabies }\end{array}$ \\
\hline
\end{tabular}

Sources: Jones and Garcia (2022); Jones et al., (2020);

Mohammed et al., (2018); Brown-Uddenberg (2001).

de Thoisy et al., 2000) have been found in wild agouti populations. However, in the captive reared colonies of agoutis blood parasites were not identified (Jones et al., 2019). Sub-clinical illnesses in the agouti have been detected using haematology and serum biochemistry. Baas et al. (1976) reported on blood reference values for agoutis reared in captivity. Further work by Jones et al. (2019) and Jones and Garcia (2019a, b) recorded blood parameters for healthy agoutis reared intensively.

\section{Methodology}

The agouti breeding unit at the University Field Station (UFS) was commissioned in 1996. The animals are primarily used in the research of this unique species. There are 150 animal kept with surplus animal provided to commercial farmers. The adult body weight of males and females at the unit range from 2 to $3.5 \mathrm{~kg}$. The gestation period one average is 117 days; females produce between one to four (average $1.70 \pm 0.4$ ) offspring per parturition. Birth weight of these animals ranged between 140 to $330 \mathrm{~g}(210 \pm 35)$ (Jones and Garcia, 2022; Jones et al., 2020; Mohammed et al., 2018; Brown-Uddenberg, 2001).

\subsection{Case Description 1}

Agoutis were housed in breeding colonies at the University Field Station (UFS). The animals are housed in breeding groups at a stocking density of $4 \mathrm{~m}^{2}$ per animal, once pregnancy is confirmed animals are moved into maternity cages $(0.61 \mathrm{~m} \times 0.91 \mathrm{~m} \times 0.61 \mathrm{~m})$. Females are kept in the maternity cages one month prior to parturition The building is open sided and animal were fed locally available feedstuff and pelletized rabbit ration (17\% crude protein) ad libitum. Locally available feedstuff included fruits such as mangoes (Mangifera indica), pumpkins (Cucurbita pepo) and fat pork (Chrysobalanus icaco). Chicken eggs were also fed to the agouti. Animals in the unit always had a constant supply of water for drinking and thermoregulation. The agouti in this study was reared on concrete floor pen which had a female to male ratio of $5: 1$. 
Confirmation of pregnancy was noted using physical signs such as a rounded abdomen and protruding nipples. The animal was primiparous female, 18 months of age and weighed approximately $3 \mathrm{~kg}$. This animal had no observable dental problems and had a good appetite. This animal received no additional dietary supplementation during gestation; the diet stated above has been reported as adequate for other captive reared colonies (Mc Williams 2009). Pregnant agoutis were observed daily for any signs of physical abnormality which included abnormal discharges from the vulva, diarrhea and emaciation. Animals were also observed for any signs of physical trauma or wounds which may have occurred as a result of fighting.

This adult female agouti ( $D$. leporina) was found dead in a maternity cage with the hind-limbs of the offspring protruding from the vulva (Figure 1). Necropsy was performed to identify any abnormalities in fetal positioning. The animal had no prior signs of illness. This situation did not allow for the agouti to be treated for its dystocia. The abdominal cavity of the agouti was incised and a right uterine horn was distended with two fetuses and no fetus was observed in the left uterine horn. The left uterine horn was not distended and showed no signs of recent implantation of an embryo that had reabsorbed. The urinary bladder of the animal was also distended (Figure 2). Neither histopathology nor urine analysis were performed on the agouti carcass.

The right uterine horn was incised and two fetuses each weighed approximately $200 \mathrm{~g}$, which is within the normal weight range for a newborn agouti. The fetuses

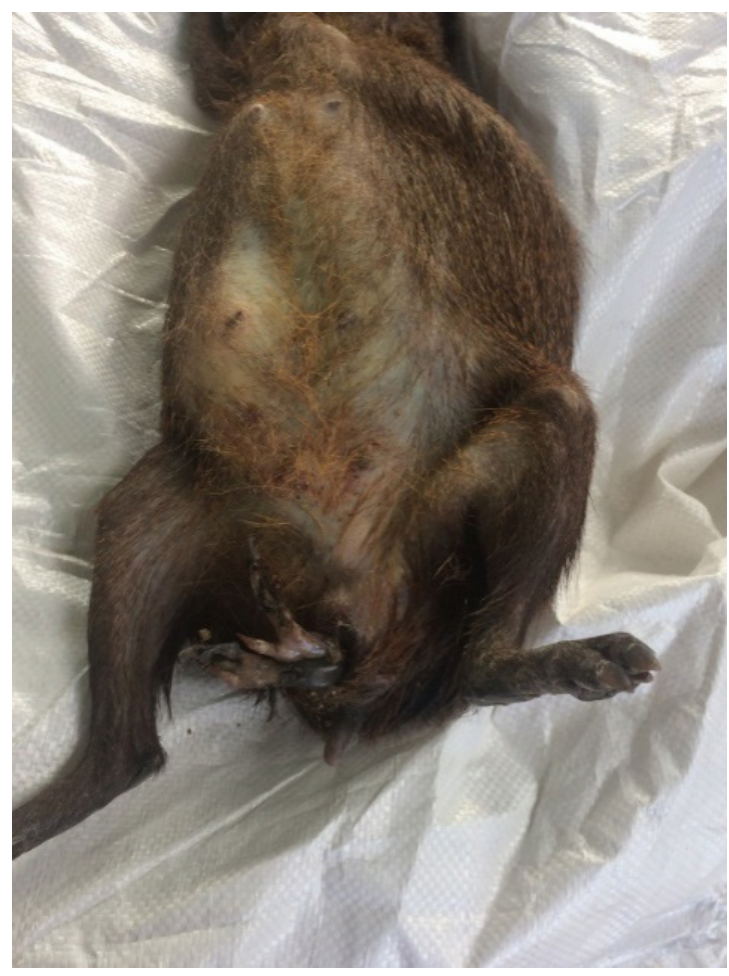

Figure 1. Adult Agouti with hind-limbs of offspring protruding from the vulva. were in posterior longitudinal presentation, dorsal position and in normal posture. The offspring had hair, teeth and nails with the placenta attached to each animal (Figure 3). The development of the fetuses having hair, nail and teeth would suggest that they were in their final stages of gestation (older than 100 days) (Oliveira et al., 2017). The carcass had little subcutaneous fat (healthy agoutis usually have little subcutaneous fat) and the cause of death was attributed to secondary uterine inertia due to the dystocia.

\subsection{Case Description 2}

Upon presentation the agouti was bright, alert and responsive. The female agouti was presented three week post-partum and its offspring was still being nursed. The birth weight of the offspring was $235 \mathrm{~g}$. The female had a red cylindrical protrusion from the genital region that measured $2 \mathrm{~cm}$ in length (Figure 4 ). The animal had good appetite and showed no other signs of abnormalities. At parturition there were no observable complications noticed. This animal belonged to the same breeding unit as the animal reported in the earlier case description. The animals' diet was the same as that reported in the earlier case.

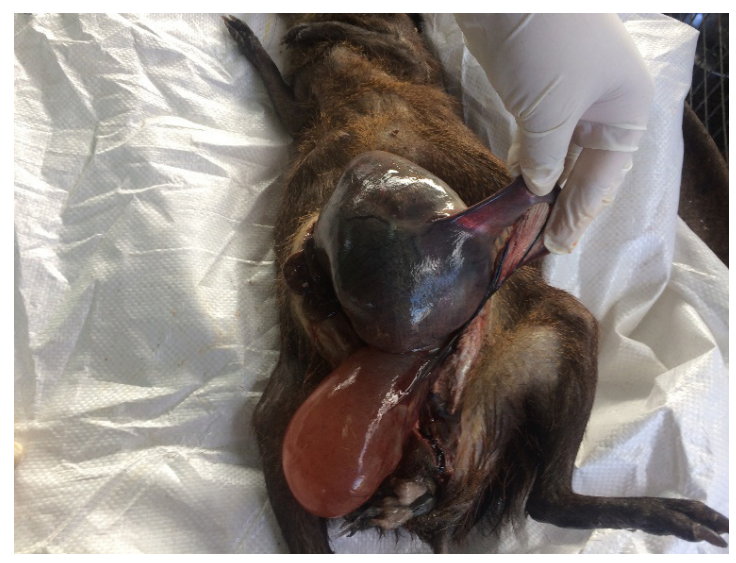

Figure 2. Necropsy of Adult Agouti with offspring in the right uterine horn and enlarged bladder (Source: Jones et al.,2020).

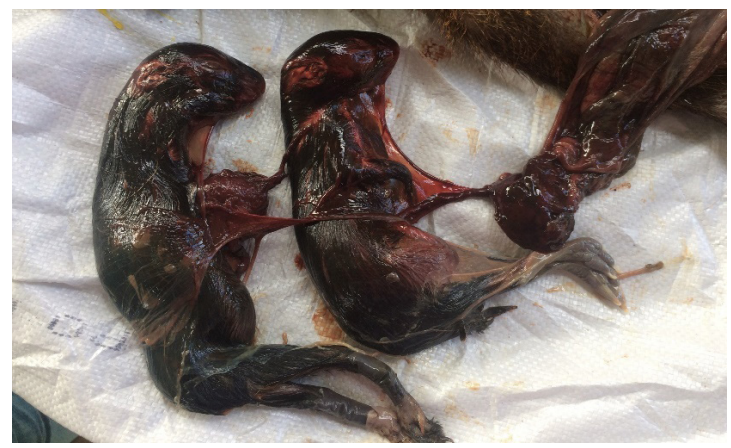

Figure 3. Two agouti offspring weighing $200 \mathrm{~g}$ each found in the left uterine horn. (Source: Jones et al., 2020). 
The female agouti was then sedated using ketamine (40 mg/kg IM) and xylazine ( $2 \mathrm{mg} / \mathrm{kg}$ IM). Gas anesthesia was not performed in this case. The agouti was then examined and the red cylindrical protrusion from the caudal end of the animal was purported to be a vaginal prolapse. Differential diagnoses at this stage could have been a rectal prolapse or a uterine prolapse. Rectal prolapse was ruled out since the protrusion was not from the anus. Uterine prolapse was ruled out due to the size of the protrusion as well as the both uterine horns were not felt on palpation.

The prolapsed tissue was cleaned with dilute chlorhexidine solution and the edema was reduced using a $50 \%$ dextrose solution. The prolapse was then lubricated and replaced manually. A $3 \mathrm{~mL}$ syringe was inserted into the vagina and a purse string suture was placed using 2-0 proline around the vagina (Figure 5 ). Post operatively the agouti was given amoxicillin ( $25 \mathrm{mg} / \mathrm{kg} \mathrm{SC}$ ) and

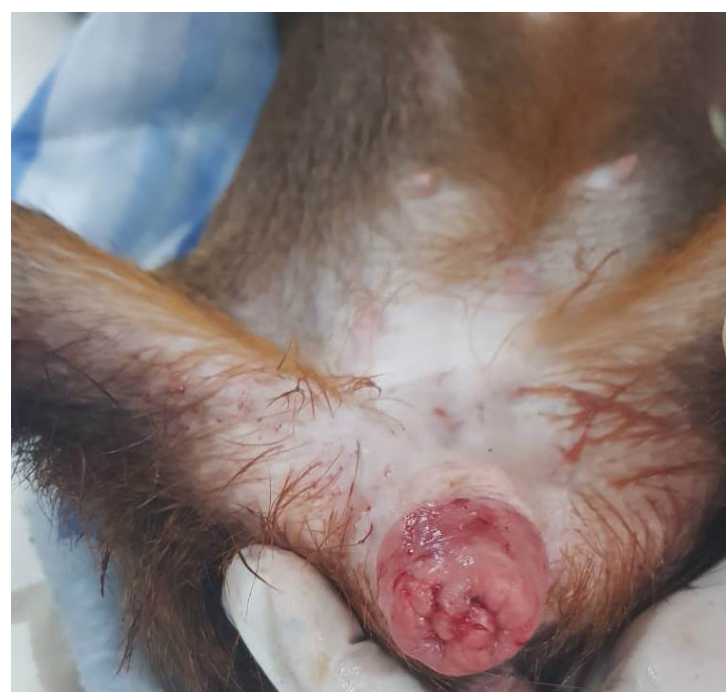

Figure 4. Vaginal prolapse of a female agouti three weeks postpartum.

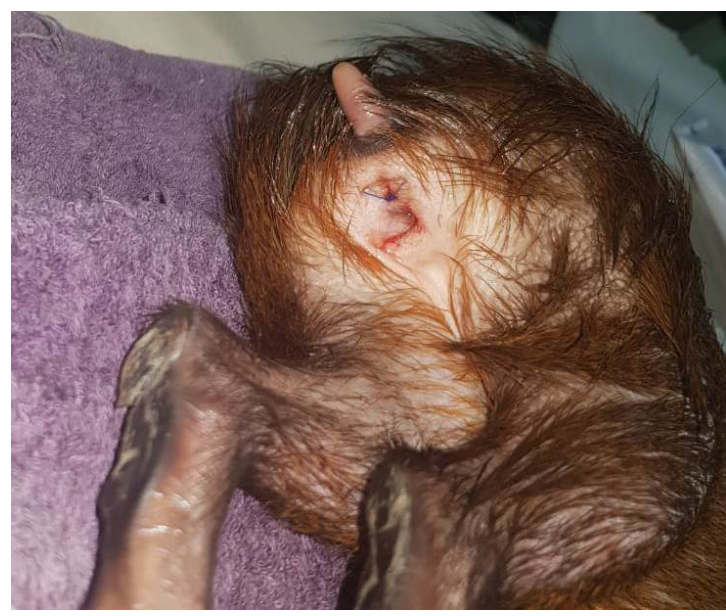

Figure 5. Vaginal prolapse inserted into the pelvic cavity postoperatively. meloxicam (1 mg/ kg SC). The following day, when the agouti was not under sedation the vagina prolapsed again. The agouti was then sedated using the same procedure as describe earlier but a $1 \mathrm{ml}$ syringe was placed into the vagina. The animal was then placed into the pen with its offspring. A day later and the vaginal tissues prolapsed for the third time. The animal was subsequently euthanized due the recurrence of this problem. The animal had to be euthanized because she was part of a breeding colony and surgical removal of the reproductive tract was not an option.

\subsection{Case Description 3}

Agoutis were housed in breeding colonies at the University Field Station (UFS) with similar enclosure and diet as mentioned in the first case. This adult female agouti ( $D$. leporina) was found dead in a maternity cage the vulva had had a bloody discharge upon presentation (Figure 6). The pregnant animal was help in the maternity cage one month before parturition. Necropsy was performed to identify any abnormalities in fetal positioning. The animal had no prior signs of illness. This situation did not allow for the agouti to be treated for its dystocia. The abdominal cavity of the agouti was incised and the left uterine horn was distended with two fetuses and no fetus was observed in the right uterine horn. The right uterine horn was not distended and showed no signs of recent implantation of an embryo that had reabsorbed. The urinary bladder of the animal was also distended. Neither histopathology nor urine analysis were performed on the agouti carcass.

The left uterine horn was incised and two fetuses each weighed $235 \mathrm{~g}$ and $165 \mathrm{~g}$ was recovered. The fetuses were in anterior longitudinal presentation, dorsal position and in normal posture. The offspring had hair, teeth and nails with the placenta attached to each animal (Figure 7). The development of the fetuses having hair, nail and teeth would suggest that they were in their final stages of gestation (older than 100 days) (Oliveira et al., 2017). The head of the fetus was occluded in the pelvic canal which caused the head of the fetus to be distorted (Figure 8). No other abnormalities were noticed grossly on the fetus. The cause of death was attributed to secondary uterine inertia due to the dystocia.

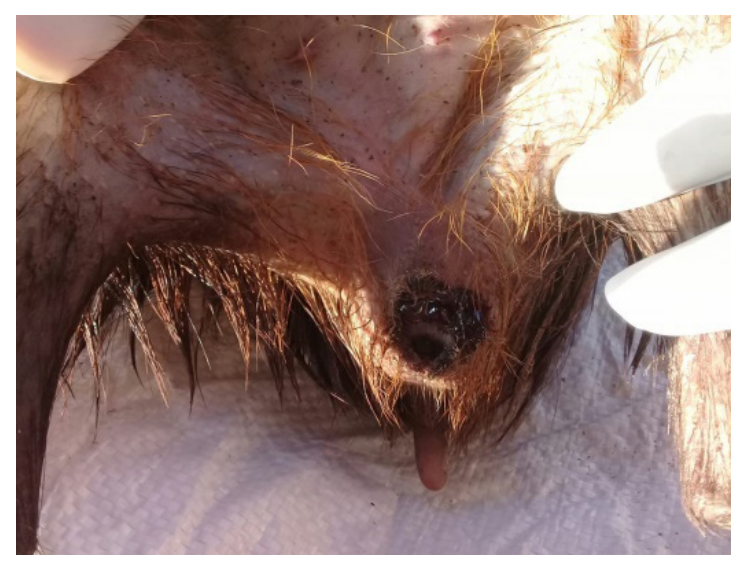

Figure 6. Bloody discharge found in the agouti upon presentation. 


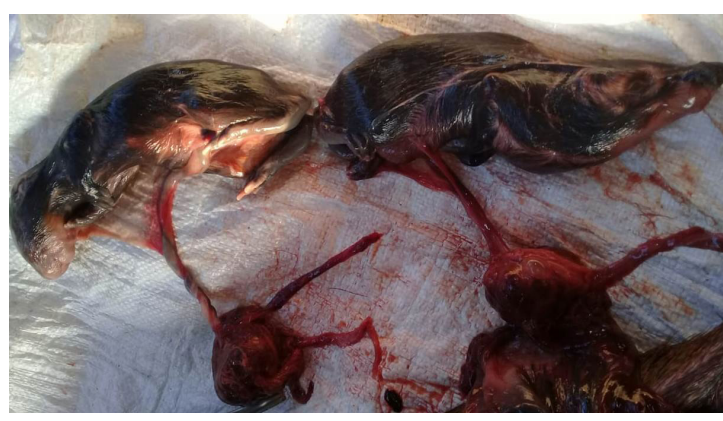

Figure 7. Fetuses with fetal membrane and placental attachments.

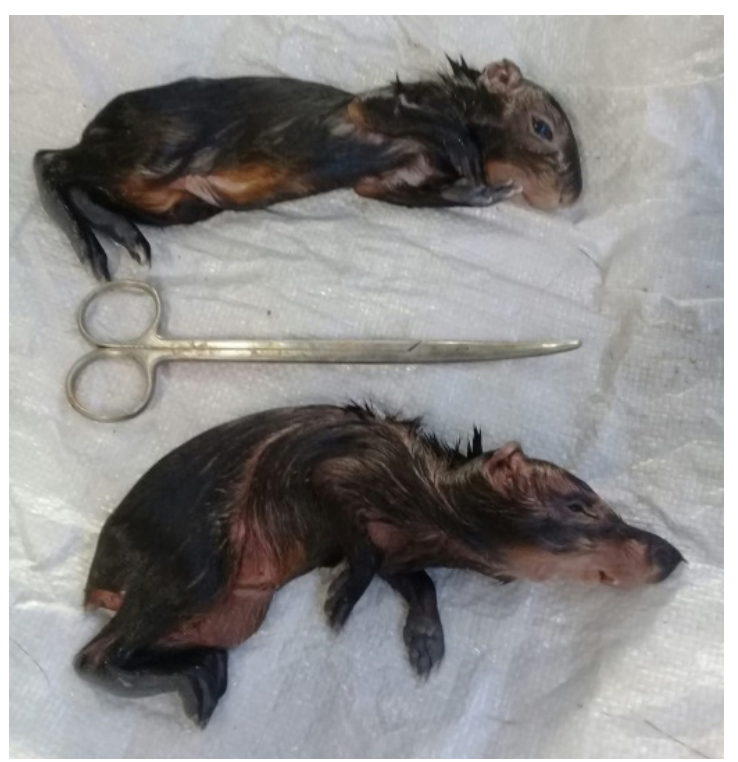

Figure 8. Fetuses found in the left horn weighing $165 \mathrm{~g}$ and $235 \mathrm{~g}$ (Note the distorted face on the bottom fetus).

\section{Discussion}

Dystocia is the inability to expel the fetus from the uterus during parturition (Sankar et al., 2017). Dystocia is a common occurrence in domestic animals. It can be due to maternal or fetal abnormalities (Sankar et al., 2017). Maternal abnormalities include small pelvic size, narrow pelvic canal and uterine inertia. Fetal causes are due to mal-presentation, mal-position, mal-posture, oversized fetus, fetal death or fetal monsters (Sankar et al., 2017). The oversized fetus can be due to over nutrition or lack of exercise by the mother during pregnancy. In rabbits, treatment of dystocia can be conservative or surgical., Conservative management was reported to be the first treatment option for rabbits. Pharmacological treatment included administration of calcium gluconate $(100 \mathrm{mg} / \mathrm{kg} \mathrm{IM})$ and oxytocin (1 IU/animal IM) (Carpenter, 2005). The calcium and oxytocin have been reported to increase the contractile strength in the uterus. Propylene glycol provides energy for the smooth muscles in the myometrium (Dickie, 2011). Surgical treatments performed include a caesarean section in the affected female. Surgical options have been performed when conservative treatments of the dystocia have failed. In this case the animal was found dead in its enclosure. There was no opportunity for any interventions to be made in this case.

In the first case the cause of death was presumed to be secondary uterine inertia due to dystocia. There was abnormal presentation but normal posture and position of the fetuses. However, the both fetuses were large and present in the right horn which may have contributed to the dystocia. Some authors stated that these animals weigh $147 \mathrm{~g}$ at birth (Lopez et al., 2004). However, other authors have found birth weights to range from $140-330 \mathrm{~g}$ (Jones and Garcia, 2022). Therefore, the fetuses in both cases were with normal range. However, a contributing factor can be the diet of the agouti and the lack of exercise. In another neo-tropical rodent (cabybara) high energy and protein in the diet of pregnant animals predisposed them to dystocia (Nogueira-Filho and Nogueira, 2013). Thus capybara breeders fed pregnant animals less than $20 \%$ of their voluntary feed intake (Mendez and Nogueira-Filho, 2013). In these cases of reported reproductive problems animals were given concentrate and local feedstuff ad libitum. Also, there is no information on the appropriate cage size for pregnant agoutis. The limited space in the cages may have decreased the level of exercise of these pregnant animals. In reproductive anatomical work done the uterine horns were reported to be independent and connected to separate cervices (Mayor et al., 2011). Therefore, there would have been some difficulty for two large fetuses to pass through the right cervix due to the agoutis' reproductive anatomy. Further work done by Singh et al., (2014) were in disagreement with Mayor et al., (2011) and stated that the agouti had one cervix and the two uterine horns connected to the body of the uterus which was connected to a common cervix. Other hystricomorphic rodents such as the capybara (Hydrochaerus hydrochaeris) and the lappe (Agouti pacal Cuniculus paca) had uterine tubes that were independent of each other and were connected independently to two cervices (Matamoros, 1981; Miglino et al., 2013). The chinchilla (Chinchilla lanigera) was reported to have two cervices which were independent of each other; both cervices were connected to its respective uterine horns (Jarrett et al., 2016). The viscacha (Lagostomus maximus) (also a hystricomorphic rodent) was found to have a nonmuscular cervix with each uterine horn opening separately into the vagina (Weir, 1971a).

Early observations on parturition in the agouti by Enders (1931) stated that new born animals were fully haired, had open eyes and were patterned like the adult. Enders (1931) also reported a dystocia that resulted in the death of mother and offspring. The right hind limb of the fetus was engaged resulting in failure to expel uterine contents. This engagement of the right hind-limb was similar to the first case. Weir (1971b) also reported a case of dystocia where the fetus was reported as being oversized and was found in the right uterine horn. In this case however, the fetuses had average birth weights (Enders 1931) and were found in the right horn which was found in a similar report (Weir 1971b). 
Prevention of dystocia can be done if accurate stages of gestation can be investigated. Sousa et al. (2012) monitored gestation age and embryonic-fetal development in the agouti. It was noted that gestational length was 103 days and using ultrasonography the gestational sac can be observed from day nine (Sousa et al., 2012). Brown (1936) stated that the gestational period for the golden-rumped agouti (Dasyprocta aguti) was 104 days. Pachaly et al. (2001) reported a gestational period of 103 days. However, Clarke and Olfert (1986) gave a gestational period ranging from 104-120 days. Guimaraes et al. (1997) found the gestational period to be $104.33 \pm 0.57$ days. Hormones such as progesterone can also be used to monitor pregnancy and embryonic development. Using plasmatic progesterone, the gestational period was found to be 104 \pm 1.31 days (Guimaraes et al., 2011). Fortes el al. (2012) highlighted that at twenty-five days after mating the fetus was positioned in a "C Shape" with primitive structures. If ultrasonography was performed on the female agouti showing signs of dystocia, then pharmacological or surgical intervention would have been made to avoid the deaths of mother and her offspring. Vaginal prolapse has never been reported in the agouti. However, it frequently occurs in domesticated livestock such as cattle and pets such as dogs. Therefore, a similar surgical treatment procedure was used on the agouti, with gentle manipulation of the vagina it was inserted into the pelvic cavity and secured with sutures.

In future, the causes of these reproductive diseases can be investigated. The effect of nutrition and activity of the agouti can be observed as contributing factors for reproductive diseases in these animals.

\section{Conclusion}

In the first and third cases the proposed cause of death was due to difficulty in parturition (dystocia). The two fetuses were found in one horn which may have attributed to the dystocia. There has been little information reported on the reproductive disorders of the agouti. The second case reported a vaginal prolapse in an agouti three weeks post-partum. Both outcomes were fatal., In the three cases reported nutrition and exercise can be contributing factors to dystocia and vaginal prolapse in the agouti. Thus, more information needs to be documented on reproductive disorders of agoutis reared in captivity. This will allow for earlier corrective measures to be taken and a decrease in mortality of these cases. The use of reproductive techniques in the assistance of these animals is pivotal for conservation and utilization of these animals. Intensification of the agouti breeding may reveal a higher incidence of reproductive diseases and treatment of such cases should be reported.

\section{References}

ANDERSON, K.M., LEWANDOWSKI, A. and DENNIS, P.M., 2018. Suspected hypervitaminosis in red-rumped agouti (Dasyprocta leporina) receiving a commercial rodent diet. Journal of Zoo and Wildlife Medicine, vol. 49, no. 1, pp. 196-200. http://dx.doi. org/10.1638/2016-0226R2.1. PMid:29517453.
AYALA, S.C., D'ALESSANDRO, A., MACKENZIE, R. and ANGEL, D., 1973. Hemoparasites in 830 wild animals from Eastern Llanos of Colombia. The Journal of Parasitology, vol.59, no. 1, pp. 52-59. http://dx.doi.org/10.2307/3278571. PMid:4631557.

BAAS, E.J., POTKAY, S. and BACHER, J., 1976. The agouti (Dasyprocta $\mathrm{sp})$ in biomedical research and captivity. Laboratory Animal Science, vol. 26, no. 5, pp. 788-796. PMid:185455.

BATISTA, J.S., OLINDA, R.G., SILVA, T.M.F., RODRIGUEZ, C.M.F., OLIVEIRA, A.F., QUEIROZ, S.A.C., MORAIS, S.R.L. and OLIVEIRA, M.F., 2010. Diseases of agouti (Dasyprocta aguti) raised in captivity diagnosed by pathological examination. The British Veterinary Journal, vol. 30, no. 6, pp. 497-502.

BATISTA, J.S., FREITAS, C.J.A., BRILHANTE, F.S., VIANA, G.A., OLINDA, R.G., CAVALCANTE, T.V., DE PAVIA, K.A.R. and DE OLIVEIRA, M.F., 2016. Pathological changes of the genital system of agoutis (Dasyprocta aguti Linnaeus, 1758) females bred in captivity. The British Veterinary Journal, vol. 36, no. 7, pp. 634-641.

BROWN, C.E., 1936. Rearing wild animals in captivity, gestational periods. Journal of Mammalogy, vol. 17, no. 1, pp. 10-13. http:// dx.doi.org/10.2307/1374541.

BROWN-UDDENBERG, R.C., 2001.Conceptualisation of an intensive production model for the agouti (Dasyprocta leporina) a neotropical rodent in Trinidad, West Indies. Kinston, Jamaica: University of the West Indies. Thesis in Livestock Science.

BROWN-UDDENBERG, R.C., GARCIA, G.W., BAPTISTE, Q.S., COUNAND, T., ADOGWA, A.O. and SAMPSON, T. 2004. [viewed 11 May 2020]. The Agouti (Dasyprocta leporina, D. aguti) Booklet and Producers' Manual [online]. Champs Fleurs, Trinidad and Tobago: GWG Publications. Available from: http://ostasp.brinkster.net/

CAMERON, T.W.M. and REESAL, M.R., 1951. Studies on the endoparasitic fauna of Trinidad mammals. Canadian Journal of Zoology, vol. 29, no. 4, pp. 276-289. http://dx.doi.org/10.1139/z51-025.

CARPENTER, J.W., 2005. Exotic animal formulary. 3rd ed. Louis: Elsevier.

CLARKE, J.D. and OLFERT, E.D., 1986. Rodents (Rodentia). In: M.E. FOWLER, ed. Zoo and Wildlife medicine. 2nd ed. Philadelphia: W.B. Saunders, pp. 728-737.

DE THOISY, B., MICHEL, J.-C., VOGEL, I. and VIE, J.-C., 2000. A survey of hemoparasite infection in free ranging mammals and reptiles in French Guina. The Journal of Parasitology, vol. 86, no. 5, pp. 1035-1040. http://dx.doi.org/10.1645/00223395(2000)086[1035:ASOHII]2.0.CO;2. PMid:11128476.

DICKIE, E., 2011. Dystocia in a rabbit (Oryctolagus cuniculus). The Canadian Veterinary Journal., La Revue Veterinaire Canadienne, vol. 52, no. 1, pp. 80-83. PMid:21461214.

ENDERS, R.K., 1931. Parturition in the agouti with notes on several pregnant uteri. Journal of Mammalogy, vol. 12, no. 4, pp. 390396. http://dx.doi.org/10.2307/1373766.

FORTES, E.A.M., FERRAZ, M.S., BEZERRA, D.O., CONDE, A.M., CABRAL, R.M., SOUSA, F.C.A., ALMEIDA, H.M., PESSOA, G.T., MENEZES, D.J.A., GUERRA, S.P.L., SAMPAIO, I.B.M., NETO, A.C.A. and DE CARVALHO, M.A.M., 2012. Prenatal development of the agouti (Dasyprocta prymnolopha, Wagler, 1831): external features and growth curves. Animal Reproduction Science, vol. 140, no. 3-4, pp. 195-205. http://dx.doi.org/10.1016/j.anireprosci.2013.06.021. PMid:23891216.

GUIMARAES, D.A., MOREIRA, D. and VALE, W.G., 1997. Determination of Agouti (Dasyprocta leporina) reproductive cycle by coplocytologic techniques. Acta Amazonica, vol. 27, no. 1, pp. 55-64.

GUIMARAES, D.A., OHASHI, O.M., SINGH, M. and VALE, W., 2011. Profile of plasmatic progesterone on pregnancy, and postpartum oestrus of Dasyprocta prymnolopha (Rodentia: 
dasyproctidae). International Journal of Tropical Biology, vol. 64, no. 4, pp. 1519-1526.

GRIFFITHS, H.J., 1940. Studies on Strongyloides agoutii from the agouti (Dasyptocta agouti). Canadian Journal of Research, Section D; Zoological Sciences, vol. 18, no. 5, pp. 173-190. http://dx.doi. org/10.1139/cjr40d-015.

HARDOUIN, J., THYS, E., JOIRIS, V. and FIELDING, D., 2003. Minilivestock breeding with indigenous species in the tropics. Livestock Research for Rural Development, vol. 15, no. 4.

JARRETT, C.L., JARRETT, T.R., HARVEY, S.B. and AWORTH, L., 2016. The uterus duplex bicollis, vagina simplex of female chinchillas. Journal of the American Association for Laboratory Animal Science; JAALAS, vol. 55, no. 2, pp. 155-160. PMid:27025806.

JONES, K.R. and GARCIA, G.W., 2017. A survey of the gastrointestinal parasites present in the Agouti (Dasyprocta leporina) reared intensively in Trinidad. Livestock Research for Rural Development, vol. 29, no. 10, pp. 1-7.

JONES, K.R. and GARCIA, G.W., 2018. Observations on endoparasitic load in captive reared agoutis (Dasyprocta leporina) without anthelmintic exposure in Trinidad, Republic of Trinidad and Tobago. Livestock Research for Rural Development, vol. 30, no. 10, pp. 1-7.

JONES, K.R., LALL, K.R. and GARCIA, G.W., 2019. Haematological and Serum biochemical values of the agouti (Dasyprocta leporina) reared intensively in Trinidad, Republic of Trinidad and Tobago. Livestock Research for Rural Development, vol. 31, no. 1, pp. 1-8.

JONES, K.R. and GARCIA, G.W., 2019a. Haematology and Serum Biochemistry in the Agouti (Dasyprocta spp.): A Neo-Tropical Rodent with the Potential for Domestication. Concepts of Dairy and Veterinary Sciences, vol. 3, no. 1, pp. 263-265.

JONES, K.R. and GARCIA, G.W., 2019b. Understanding of the Blood and Serum values of the Agouti (Dasyprocta spp.): A Rodent of the Neo-Tropics with the potential to be domesticated. Tropical Agriculture, vol. 96, no. 1, pp. 116-127.

JONES, K.R. and GARCIA, G.W., 2022. Anthelmintic usage on the reproductive parameters in captive reared Agoutis (Dasyprocta leporina) in Trinidad and Tobago, West Indies. Brazilian Journal of Biology, vol. 83, no. 3, In press.

JONES, K.R., LALL, K.R. and GARCIA, G.W., 2020. Dystocia in a captive reared Agouti (Dasyprocta leporina) in Trinidad and Tobago, West Indies. Veterinary Sciences, vol. 7, no. 1, pp. 30. http:// dx.doi.org/10.3390/vetsci7010030. PMid:32143289.

KENNY, D., CAMBRE, R.C., LEWANDOWSKI, A., PELTO, J.A., IRIBECK, N.A., WILSON, H., MIERAU, G.W., SILL, M.G., and GARCIA, A.P., 1993. Suspected vitamin $D_{3}$ toxicity in pacas (Cuniculus paca) and agoutis (Dasyprocta aguti). Journal of Zoo and Wildlife Medicine, vol. 24, no. 2, pp. 129-139.

LAINSON, R., CARNEIRO, L. and SILVEIRA, F.T., 2007. Observations on the Eineria species of the Dasyprocta leporina (Linnaeus, 1758) (Rodentia: Dasyproctidae) for the state of Para, North Brazil. Memorias do Instituto Oswaldo Cruz, vol. 102, no. 2, pp. 183-189. http://dx.doi.org/10.1590/S0074-02762007005000008. PMid:17426883.

LALL, K.R., JONES, K.R. and GARCIA, G.W., 2018. Infectious Diseases of Six Non-Domesticated Neo-Tropical Animals in Trinidad and Tobago. International Journal of Tropical Veterinary Biomedical Research, vol.3, no. 2, pp.1-31. http://dx.doi.org/10.21157/ijtvbr.v3i2.12332.

LALL, K.R., JONES, K.R. and GARCIA, G.W., 2020. Natural habitat, housing and restraint for six selected Neo-Tropical animals in Trinidad and Tobago with the potential for Domestication. Scientifica, ID, vol. 9741762, pp. 9741762. http://dx.doi. org/10.1155/2020/9741762. PMid:32300488.

LOPEZ, J.B., CAVALCANTE, R.R., DE ALMEIDA, M.M., DE CARVALHO, M.A.M., DE MOURA, S.G., DANTES FILHO, L.A. and CONCEICAO,
W.F.L., 2004. Performance of Agouti (Dasyprocta leporina) bred in captivity according to sex and parturitions in Teresina, Piaui. Revista Brazileria Zootechnica, vol. 33, no. 6, pp. 2318-2322.

MATAMOROS, Y., 1981. Anatomia e histologia del Sistema reproductor del tepezcuinte (Cuniculus paca). Revista de Biología Tropical, vol. 29, no. 1, pp. 155-164.

MAYOR, P., BODMER, R.E. and LOPEZ-BEJAR, M., 2011. Functional anatomy of the female genital organs of the wild black agouti (Dasyprocta fuliginosa) female in the Peruvian Amazon. Animal Reproduction Science, vol. 123, no. 3-4, pp. 249257. http://dx.doi.org/10.1016/j.anireprosci.2010.12.006. PMid:21216112.

MCWILLIAMS, D.A., 2009. Determinants for the diet of captive agoutis (Dasyprocta spp.). The Veterinary Clinics of North America. Exotic Animal Practice, vol. 12, no. 2, pp. 279-286, ix. http://dx.doi.org/10.1016/j.cvex.2009.01.001. PMid:19341954.

MENDEZ, A. and NOGUEIRA-FILHO, S.L.G. 2013. Feed And nutrition of farmed capybaras. In: J.B. MOREIRA, K.M.P.M.B. FERRAZ, E.A. HERRERA and D.W. MACDONALD. Capybara: Biology, use and conservation of an exceptional neotropical species. New York: Springer Science+Media Business. http://dx.doi.org/10.1007/9781-4614-4000-0_15.

MINARIKOVA, A., HAUPTMAN, K., JEKLOVA, E., KNOTEK, Z. and JEKL, V., 2015. Diseases in pet guinea pigs: a retrospective study in 1000 animals. The Veterinary Record, vol. 177, no. 8, pp. 200. http://dx.doi.org/10.1136/vr.103053. PMid:26198213.

MIGLINO, M.A., DOS SANTOS, T.C., KANASHIRO, C. and DOS SANTOS FERRAZ, R.H., 2013. Morphology and reproductive physiology of female Capybaras. In: J.B. MOREIRA, K.M.P.M.B. FERRAZ, E.A. HERRERA and D.W. MACDONALD. Capybara: Biology, use and conservation of an exceptional neotropical species. New York: Springer Science+Media Business.

MOHAMMED, R., LEGALL, G. and GARCIA, G.W., 2018. Towards the determination of a "Weaning Age" for the intensive production of the Agouti (Dasyprocta leporina). Livestock Research for Rural Development, vol. 30, no. 10.

NOGUEIRA-FILHO, S.L.G. and NOGUEIRA, S.S.C., 2013.The impact of management practices on female capybara reproductive parameters in captivity. In: J.B. MOREIRA, K.M.P.M.B. FERRAZ, E.A. HERRERA and D.W. MACDONALD. Capybara: Biology, use and conservation of an exceptional neotropical species. New York: Springer Science+Media Business. http://dx.doi. org/10.1007/978-1-4614-4000-0_16.

OLIVEIRA, G.B., DE ARAUJO JUNIOR, H.N., SILVA COSTA, H., SILVA, A.R., MOURA, C.E.B., DE OLIVEIRA ROCHA, H.A., MIGLINAO, M.A. and OLIVEIRA, M.F., 2017. Post-implantation development of red-rumped agouti (Dasyprocta leporina Linnaeus, 1758). Animal Reproduction Science, vol. 182, pp. 35-47. http://dx.doi. org/10.1016/j.anireprosci.2017.04.007. PMid:28502649.

PACHALY, J.R., ACCO, A., LANGE, R.R., NOGUIERA, T.M.R., NOGUIERA, M.F. and CIFFONI, E.M.G., 2001. Order Rodentia (Rodents), In: M.E. FOWLER and Z.S CUBAS, ed. Biology, medicine and surgery of South American mammals (2nd ed.). Ames, Iowa: Iowa State University Press, pp. 225-237.

RUBEL, A., 1999. Husbandry and Pathology of rodents and lagomorphs in Swiss Zoos. Verh.ber. Erkg. Zootiere vol. 39, pp. 241-254.

SANKAR, P., MANDAL, D., KUMAR, V. and MONDAL, M., 2017. Dystocia in rabbits and its surgical management. Exploratory Animal and Medical Research, vol. 7, no. 2, pp. 216-217. 
SAUNDERS, R., 2009. Veterinary care of chinchillas. In Practice, vol. 31, no. 6, pp. 282-291. http://dx.doi.org/10.1136/ inpract.31.6.282.

SINGH, M.D., ADOGWA, A.O., MOLLINEAU, W.M. and GARCIA, G.W., 2014. Gross and microscopic anatomy of the reproductive tract of the female agouti (Dasyprocta leporina): A neotropical rodent with the potential for domestication. Tropical Agriculture (Trinidad), vol. 91, no. 1, pp. 38-46.

SINGH, M.D. and GARCIA, G.W., 2015. Perimortality in a Captive Reared Agouti (Dasyprocta leporina). Wildlife Biology in Practice, vol. 11, no. 2, pp. 70-74.

SOUSA, F.C.A., ALVES, F.R., FORTES, E.A.M., FERRAZ, M.S., MACHADO JUNIOR, A.A.N., MENEZES, D.J.A. and DE CARVALHO, M.A.M., 2012. Pregnancy in Hystricomorpha: gestational age and embryonic-fetal development of agouti
(Dasyprocta prymnolopha, Wagler 1831) estimated by ultrasonography. Theriogenology, vol. 78, no. 6, pp. 1278-1285. http://dx.doi.org/10.1016/j.theriogenology.2012.05.023. PMid:22898012.

SUEPAUL, R., CHARLES, R. and DZIVA, F., 2016. Aerobic microflora and endoparasites of freshly shot wild Agouti (Dasyprocta leporina) in Trindad, West Indies. Journal of Zoo and Wildlife Medicine, vol. 47, no. 4, pp. 1044-1048. http://dx.doi.org/10.1638/20150055.1. PMid:28080916.

WEIR, B.J., 1971a. The reproductive organs of the female plains viscacha, Lagostomus maximus. Journal of Reproduction and Fertility, vol.25, no.3, pp.365-373. http://dx.doi.org/10.1530/jrf.0.0250365.PMid:5579689.

WEIR, B.J., 1971b. Some observations on reproduction in the female agouti, Dasyprocta aguti. Journal of Reproduction and Fertility, vol. 24, no. 2, pp. 203-211. http://dx.doi.org/10.1530/jrf.0.0240203.PMid:5102535. 